\title{
Development of a Modified Environment for Oyster Mushroom (pleurotus ostreatus) Production System for Rural Use in Southeast Nigeria
}

\author{
B. U. Ogbu, W. I. Okonkwo, S. N. Ugwu* \\ Department of Agricultural and Bioresources Engineering, University of Nigeria, Nsukka, Enugu State, NIGERIA.
}

\begin{abstract}
This study investigated a Pleurotus ostreatus production in Nsukka, Nigeria, using the locally available materials. A modified controlled environmental system capable of maintaining the micro elements (temperature and relative humidity) suitable for cultivation of oyster mushroom was developed. The system was tested using substrates of biomaterial origin (saw dust and rice bran) at different levels of treatments. The substrates used were fermented sawdust supplemented with rice bran at a spawning level of 0\%, 5\%, 10\%, 15\%, and 20\%. The steps involved in the cultivation were composting, bagging, spawning, incubation and cropping the substrates. The experiment was laid out in a completely randomized design in five replications and results analysed at $P<0.05$ significant difference. The biological efficiency was determined to establish the minimum suitable nutrient supplementation levels and the best yield of Pleurotus ostreatus. The nutritional compositions of the yield were analysed. The highest mean yield of $24.5 \mathrm{~g}$ of fresh mushrooms was observed with the substrate mixture T3 (15\% rice bran and 85\% saw dust) and lowest yield of $8.6 \mathrm{~g}$ observed in the TO (without rice bran). The effects of temperature and relative humidity on growth of oyster mushroom were evaluated. The result of this study showed that small-scale, indoor oyster mushroom production appears to be economically feasible in Nsukka.
\end{abstract}

Keywords: Pleurotus ostreatus, mushroom, substrate, environment

\section{INTRODUCTION}

In developing climes, an estimated 150.8 million persons especially are stunted and suffers impairment of the immune control, owing to protein deficiency $[1,2]$. Most traditional sources of protein in Nigeria such as, eggs, meats, milk, are expensive [3]. The foregoing necessitates the search for alternatives protein sources like mushrooms, which are rich in protein, vitamin and other minerals [4]. China produces $64 \%$ of all edible mushrooms in the world and $85 \%$ of all oyster mushrooms all over the world (Pleurotus spp.) are also produce in China [5].

Oyster mushroom (Pleurotus $s p$ ) is of the Tricholomataceae family and naturally found as clusters on moist dead woody plants, it degrades lignocellulosic wastes, enabling to it grow on different types of agricultural waste at wide temperature ranges $\left(15^{\circ} \mathrm{C}-35^{\circ} \mathrm{C}\right)$ and extremely high relative humidity range of between $85 \%$ and $100 \%$ [6-8]. In the research of [4], it was reported that optimal temperature for the growth of oyster mushroom species was attained at $28^{\circ} \mathrm{C}$. The Oyster

*(Tel: +234 (0)703949 0818)

Email addresses: ogbu_bernard@yahoo.com (B. U. Ogbu), wilfred.okonkwo@unn.edu.ng (W. I. Okonkwo), samnnaemeka.ugwu@unn.edu.ng (S. N. Ugwu) mushroom, among all edible species is the second most cultivated type globally due to its high biological efficiency, shorter growth time, low cost of production, medicinal and nutritional values $[9,10]$. According to $[11,12]$, the nutritional value of oyster mushroom can be compared to that of eggs, milk and meat and are a rich in water (90\%), proteins, vitamin (thiamine, riboflavin, folic acid, and niacin) and other minerals $(\mathrm{P}, \mathrm{Ca}, \mathrm{Fe}, \mathrm{K}$, and $\mathrm{Na}$. FAO [5] reported that the income from edible mushrooms is an important source of revenue for rural communities. The high nutritional, ecological, economical and medicinal values of Pleurotus spp., necessitated our preference for it in our in this study.

Aside the cultural media, lignocellulosic substrate (rich in carbon and nitrogen), grain sources, climatic condition (especially temperature and humidity) is another important factor for production of oyster mushroom [4]. The changes of both temperature and humidity due to diurnal and seasonal variations made the development of a controlled environment from cheap and locally sourced materials in this study necessary for maintenance of optimum relative humidity and temperature and ensuring all year production of oyster mushroom. 


\section{MATERIALS AND METHODS}

\subsection{Design and Process Description}

The mushroom growing house (MGH) of crosssectional area $32 \mathrm{~m}^{2}$ located at Nsukka, Nigeria, latitude $6.81 \mathrm{~N}$ is shown in Fig. $1(\mathrm{a})$ and (b) is a passive structure for modification of mushroom growing environment. The house is made up of $0.2 \mathrm{~m}$ thick mud wall with two openings were positioned northern and southern walls for ventilation. The floor was covered with plastic to prevent water seepage and filled with river sand, the growing house is roofed with thatched grass and an access door to the building was also installed.

The periodically wetted river sand-filled floor was used to maintain high humidity and regulate in the MGH. The mushroom growing bags were kept moist and to ensure quality produce, plastic insulation was installed to avert moist migration, control air movement and overall control of the growing environment. The mushroom bags were stacked as shown in Fig. 1(c) to enable air flow and conveyance of needed heat to the microclimate of substrate bags. The relative humidity $(\mathrm{RH})$ inside the growing house were kept between $62-79 \%$ by watering the sand floor and spraying the substrate bags with water twice a day in the morning and evening during cropping.

The nutrient content tested for include potassium, magnesium, nitrogen, phosphorus, calcium, copper, manganese, vitamins A, B \& C, fibre content and moisture content. All the nutritional analysis was done in Home Science, Nutrition and dietetics laboratory, University of Nigeria, Nsukka.

The bundles of thatch grass for roofing, mud block, wood (roofing material), river sand, growing substrate (sawdust), rice bran, clean water, plastic bags (substrate containers), rubber pipe (aeration of substrate bag), etc. were sourced locally at the Nsukka market and the neigbouring rice mill at Adani, Enugu State. The spawn, Pleurotus ostreatus (oyster mushroom seeds) were bought from biotechnology laboratory, Federal Institute of Industrial Research; Oshodi Lagos. CRECER Digital Hygrometer was used for obtaining temperature and relative humidity hourly readings.

\subsection{Experimental Design}

Fresh wood sawdust was collected from the timber sawmills at Nsukka. The sawdust was heaped to about $0.5 \mathrm{~m}$ in height and water in the ratio of 1: $2(\mathrm{v} / \mathrm{v})$ was added onto the heap on a platform and mixed thoroughly. The heap was covered with black plastic polyethylene sheet and left to ferment for 28 days with regular turning once a week. After 28 days, when the moisture content had dropped to $72 \%$, and the supplemented with rice bran as shown in Table 1 . After proper mixing, $500 \mathrm{~g}$ of each mixed substrate was filled in plastic bag ( $12.5 \mathrm{~cm}$ wide and $18.5 \mathrm{~cm}$ long). The bags inoculated with the spawns of oyster mushroom at the rate of 5\% per bag according to the dry weight of substrates and kept at room temperature and average relative humidity of $70 \%$ for

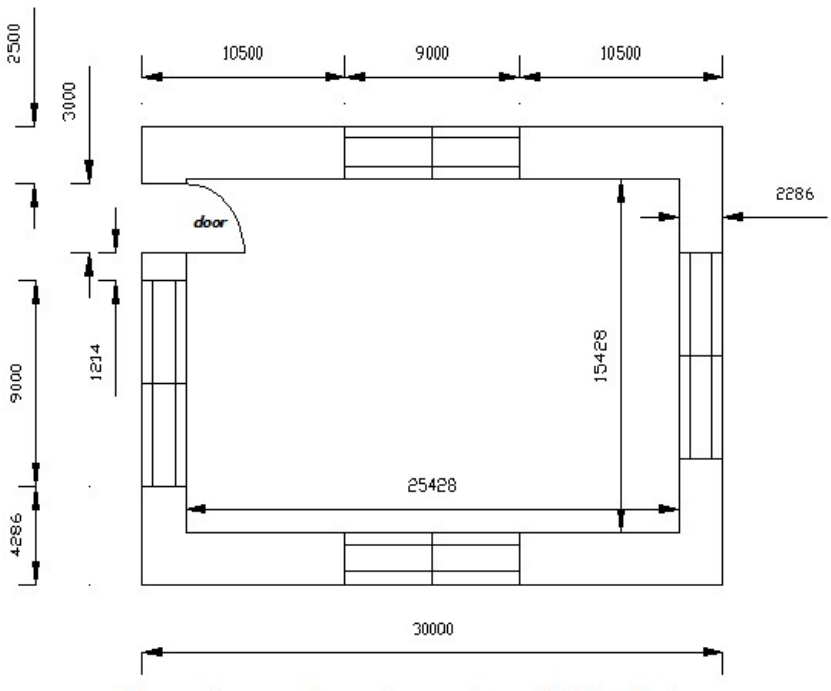

(Dimensions are in metre, scale $=10000$ units)

(a) Plan view of oyster growing house.

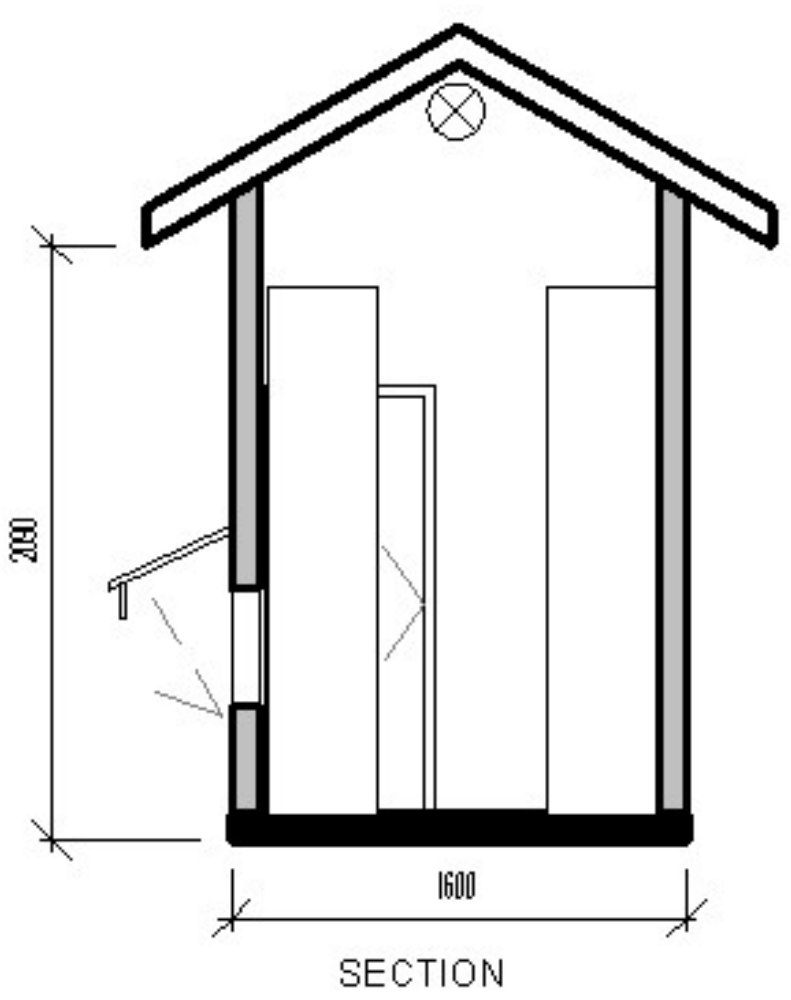

(b) Cross sectional view.

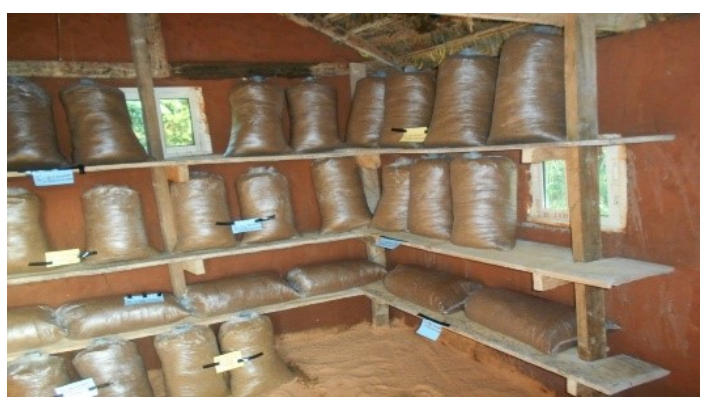

(c) Interior view of the mushroom house during load test

Figure 1: (a) Plan view of oyster growing house (b) Cross sectional view. (c) Interior view of the mushroom house during load test. 
Table 1: percentages of substrate combinations.

\begin{tabular}{ll}
\hline Notations & Treatments combinations \\
T0 & 100\% fermented sawdust substrate $+0 \%$ rice bran (Control) \\
T1 & $95 \%$ fermented sawdust substrate $+5 \%$ rice bran \\
T2 & $90 \%$ fermented sawdust substrate $+10 \%$ wheat/rice bran \\
T3 & $85 \%$ fermented sawdust substrate $+15 \%$ rice bran \\
T4 & $80 \%$ fermented sawdust substrate $+20 \%$ rice bran \\
\hline
\end{tabular}

mycelium colonization. The number of contaminated bags, number of days for substrate colonization, total mushroom yield (g) and biological efficiency (BE).

The experiment followed a Completely Randomize Design (CRD) for the two substrates at varying combinations levels and five replicates as shown in Table 1.

At difference value of $15 \%$, all experiments were analysed at probability level of $\mathrm{P}<0.05$ with GenSTAT Discovery version 4.

\section{DESIGN CONSIDERATIONS AND CALCU- LATIONS}

The stage of maturity, ventilation rate (air movement), temperature, relative humidity, surface area, substrate type etc. are some of the factors considered in the design of mushroom production structures, but the control of temperature and humidity is key to achieving quality yield [13].

\subsection{Basic Theory}

The modification of the environment for oyster mushroom production involves the flow of air humidity and temperature regulation, the following were assumed: (i) the system was a passive prototype system; (ii) it was constructed on a shady and windy area and (iii) Constant spraying of water in the shad house.

\subsubsection{Quantity of airflow mass}

The universal gas law was used in determining the quantity of heat in the air mass within the mushroom room at the ambient surrounding temperature, as expressed in equations below [14].

$$
P V=n \times R \times T
$$

Where: $\mathrm{P}=$ pressure $\left(\mathrm{N} / \mathrm{m}^{2}\right)$, R- Universal gas constant for air $=8.31 \mathrm{KJ} / \mathrm{kgmolk}, \mathrm{V}$ - volume of mushroom chamber $\left(0.362 \mathrm{~m}^{3}\right)$, T- initial temperature of the mushroom chamber $(18+273)=291 \mathrm{~K}$, $\mathrm{n}=$ mole of air which is,

$$
n=\frac{m}{M}
$$

$m=$ mass of air in the mushroom chamber (kg), $M=$ molar mass of air $(28.97 \mathrm{~kg} / \mathrm{mole}$ Obtaining the gas constant $\mathrm{R}$ for the mass of air inside the mushroom chamber at room temperature $\left(25^{\circ} \mathrm{C}\right)$ in $\mathrm{kJ} / \mathrm{mole}$;

$$
R=\frac{R^{1}}{R}
$$

$R^{1}=$ gas constant for the mushroom chamber at $18^{\circ}$ is $0.287 \mathrm{~kJ} / \mathrm{K}$. Substituting for $n$ in the universal gas equation (Eq. (1)) using (Eq. (2)) to get

$$
m=\frac{P V \times M}{R T}
$$

The airflow mass needed to be heated up in the mushroom chamber is $1.256 \times 10^{-4} \mathrm{~kg}$. The quantity of heat required to heat up this mass of air is expressed according to [14], as;

$$
Q_{\text {thermal load }}=m \times C_{p} \times \Delta t
$$

Where: $m=$ mass of air in $\mathrm{kg}, C_{p}=$ specific heat of air at $18^{\circ} \mathrm{C}$ obtained as $1006 \mathrm{~kg} / \mathrm{kg}^{\circ} \mathrm{C} \Delta t$ $=$ change in temperature in the mushroom chamber from the ambient temperature $18^{\circ} \mathrm{C}$ to $43^{\circ} \mathrm{C}$ heated temperature in the mushroom chamber.

\subsubsection{Ventilation rate by cabinet effect}

Thermal buoyancy induced ventilation rate through two openings at different elevations is to be determined. The two openings are separated by difference of elevation, $\triangle h=\left(h_{2}-h_{1}\right)+\left(h_{4}-h_{2}\right)$ and the air densities for inlet and outlet vent are $\rho_{i}$ and $\rho_{o}$ respectively.

Applying the mass flow continuity relationship with two velocities at the point inflow and outflow of air we have;

$$
\rho_{o} C_{d 2} A_{2 v 2}=\rho_{i} C_{d 4} A_{4 v 4}
$$

With the known inlet velocity, the unknown outlet velocity is stated by [15] thus;

$$
\begin{aligned}
& v_{4}= \\
& \left(\frac{2 g \Delta h q_{p r o d}}{T_{0}\left[1+\left(\frac{T_{0}}{T_{1}}\right)\left(\frac{C_{d 4} A_{4}}{C_{d 2} A_{2}}\right)^{2}\right]\left[\sum U A+F P+c_{p} \rho_{i} C_{d 4} A_{4} v_{4}\right]}\right)^{\frac{1}{2}}
\end{aligned}
$$

$$
V=C_{d 4} A_{4} v_{4}
$$

Where: $V=$ Ventilation rate, $T_{0}=$ inlet air (ambient air) temperature $\mathrm{K}, T_{i}=$ outlet air temperature $\mathrm{K}, \rho_{i}=$ inlet air density at $=\mathrm{kg} / \mathrm{m}^{3}, \rho_{o}=$ outlet air density at $\mathrm{kg} / \mathrm{mm}^{3}, q_{\text {prod }}=$ total sensible heat flow $=\rho \tau I_{T} A=\mathrm{W}, \Delta \mathrm{h}=$ difference in elevation between the inlet and the outlet vent. $C_{d}=$ coefficients of discharge is taken to be $0.6 ., V_{4}=$ air velocity at the inlet $\mathrm{m} / \mathrm{s}, C_{p}=$ specific heat capacity of air $\mathrm{J} / \mathrm{KgK}, \mathrm{A}_{4}=$ area of the outlet vent $\mathrm{m}^{2}, \mathrm{~A} 4_{4}=$ area of the inlet vent $\mathrm{m}^{2}$. 


\subsubsection{Heat loss by conduction, $Q_{\text {cond }}$}

Heat loss to the environment from the growing mushroom room walls and the vent is noted in Eq. (9), $Q_{\text {conduction }}$ is heat loss to the environment through the growing mushroom room. The room wall is made of mud; it also served as an insulator. The thickness of the wall is $0.2 \mathrm{~m}$. The heat transfer through the growing mushroom room wall will be estimated using heat transfer mechanism of wall [16];

$$
Q_{\text {cond }}=\frac{\left(t_{i} t_{o}\right)}{\frac{l}{k b}} \times A
$$

Where, $A=$ total area of the mud wall, $k b=$ thermal conductivity of cabinet $(\mathrm{W} / \mathrm{mk}), t_{o}=$ temperature of the growing mushroom room $(\mathrm{K}), t_{i}=$ ambient temperature $(\mathrm{K}), l=$ the thickness of the conduction layers $(\mathrm{m})$.

\subsubsection{Heat loss by convection}

Heat loss through convective ventilation is as a result of air leaving the growing mushroom room and is expressed thus;

$$
Q_{\text {cond }}=V \rho C \triangle T
$$

Where, $V=$ ventilation rate, $\rho=$ density of the outlet air at the heated temperature, $C=$ specific heat capacity of air, $\triangle T=$ temperature difference between the growing mushroom room and ambient air.

The overall heat loss to the environment is;

$$
Q_{\text {loss }}=Q_{\text {conv }}+Q_{\text {cond }}-Q_{\text {oyster }}
$$

\subsubsection{Biological efficiency}

Biological efficiency is a measurable tool used to know the growth potential of the oyster mushroom. The biological efficiency (BE) values were calculated according to [17] as:

\section{Bio-efficiency $(\mathrm{BE})=$}

Fresh weight of mushroom (g)

$$
\text { Dry weight of substrate (g) Moisture content }
$$$$
\times 100 \%
$$

The moisture content of the substrate is expressed in percentage by weight on wet basis and state below:

$$
M=\frac{W_{m}}{W_{m}+W_{d}} \times 100
$$

Where: $W_{m}=$ weight of moisture and $W_{d}=$ weight of dry material.

\subsubsection{No-load test}

This test was done to establish the transient response of the system to variations in prevailing weather conditions in terms of temperature reduction between the ambient and the mushroom house and change in relative humidity before loading of substrate [18]. The experiment was carried out for three days. This test involved

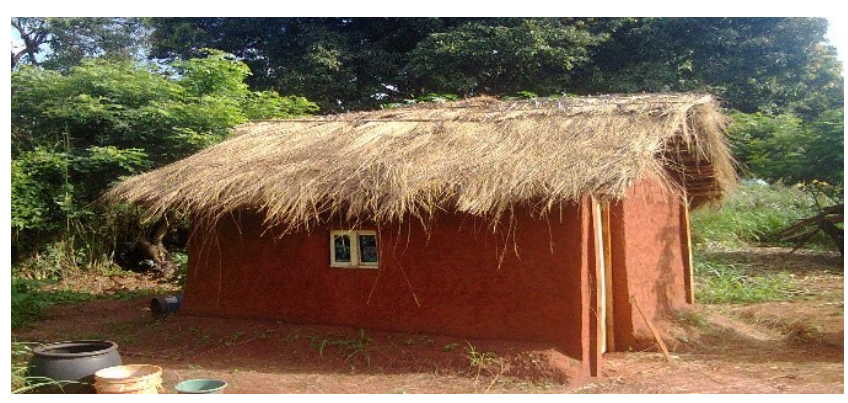

(a) External View of the local Mushroom House.

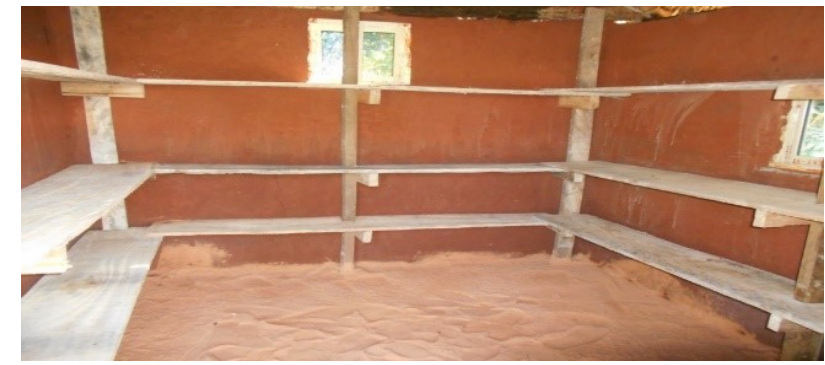

(b) Interior view of the mushroom house during no load test.

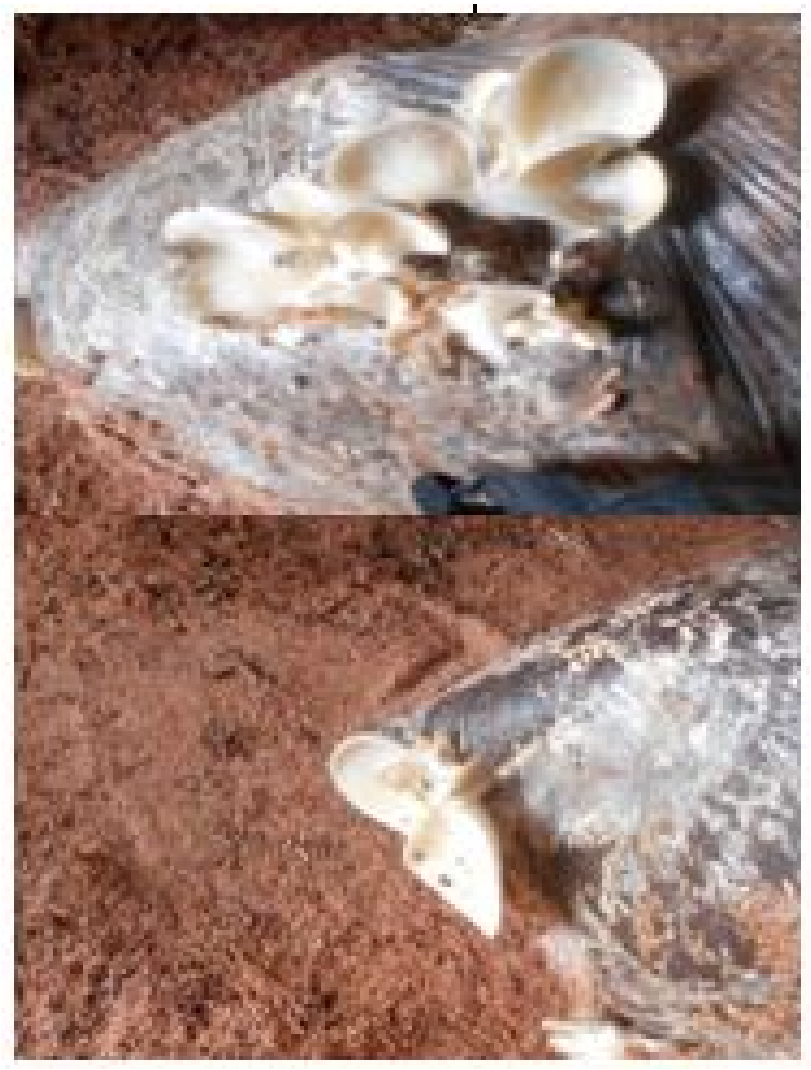

(c) Oyster mushroom growing on treated sawdust substrate.

Figure 2: (a) External View of the local Mushroom House (b) Interior view of the mushroom house during no load test. (c) Oyster mushroom growing on treated sawdust substrate. 


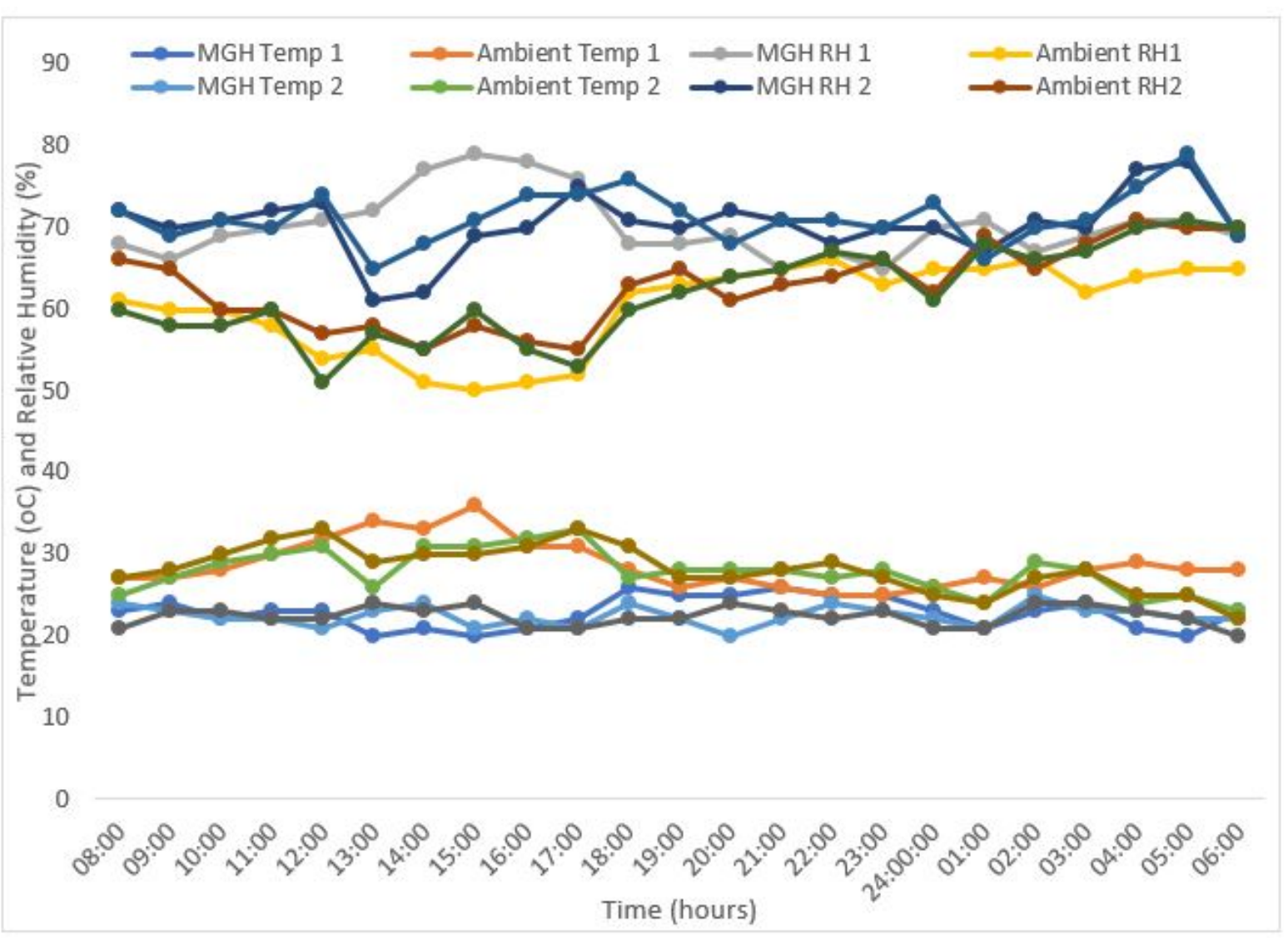

Figure 3: three days (20th -22nd November) hourly room (MGH) and ambient temperature and relative humidity.

wetting of the mushroom house with water from the water reservoir until the point of dripping and taking the readings of the required parameters. The wetting of the mushroom house was done at interval of twice daily (morning and night). Figure $2 \mathrm{~b}$. The Ambient and the room temperatures (ii) Ambient and the room relative humidity were measured and recorded daily at intervals of one hour for twenty-four (24) hours using a digital hygrometer that reads both relative humidity and temperature simultaneously.

\subsubsection{Load test}

The load test lasted for a period of ten weeks. The mushroom house was loaded with mixed substrate of fermented sawdust and rice bran supplement fig 1c. These four mixed substrates filled in plastic bag ( $12.5 \mathrm{~cm}$ wide and $18.5 \mathrm{~cm}$ long) were kept in the mushroom house and the control which was used to compare and evaluate the effectiveness of the controlled system.

\section{RESULTS AND DISCUSSION}

\subsection{Temperature and Relative Humidity Readings of No-load Test}

The average hourly and daily temperature readings for the three days no load tests are shown in Fig. 3 below. The results obtained showed that, the temperature inside the mushroom house varied from $22.43-28.47^{\circ} \mathrm{C}$ hourly with an average value of $25.45^{\circ} \mathrm{C}$ while ambient temperature varied from $25.41-34.62^{\circ} \mathrm{C}$ hourly with an average value of $30.15^{\circ} \mathrm{C}$. This implies that with the mushroom house, average temperature drop of $4.7^{\circ} \mathrm{C}$ hourly was observed. However, the maximum average temperature readings observed for ambient $\left(30-34^{\circ} \mathrm{C}\right)$ gave minimum temperature readings for the mushroom house. There was no systematic pattern in the variations of the temperature readings.

The average hourly and daily relative humidity readings for the three days are shown in Fig. 3. The average hourly relative humidity observed for 24 hours during the no load test varied from 64.98 to $72.54 \%$ with average value of $66.56 \%$, while ambient relative humidity varied from 58.52 to $72.84 \%$ with average value of $68.00 \%$ for ambient. This implies that there was relative humidity increment of $7.56-14.32 \%$. Between 12:00 hours and 16:00 hours local time, the lowest range $(59.00-65.65 \%)$ of ambient relative humidity on hourly basis was observed. The graph of variations in the average hourly relative humidity readings with time is shown in Fig. 3.

\subsection{MGH Fruiting Site Assessment}

Temperatures within the shade house got as high as $30^{\circ} \mathrm{C}$, a little above the recommended range for Oyster mushrooms. Relative humidity reached lows below recommended for Oyster mushroom cultivation. Dramatic diurnal fluctuations in both temperature and relative humidity occurred during the monitoring period as shown 
Table 2: Mean Maximum and Minimum values for temperature and relative humidity within the mushroom growing house.

\begin{tabular}{lllccccc}
\hline S/N & \multirow{2}{*}{ Months } & & \multicolumn{2}{c}{ Temperature $\left({ }^{\circ} \mathrm{C}\right)$} & \multicolumn{3}{c}{ Relative humidity (\%) } \\
& & Mean & Max & Min & Mean & Max & Min \\
\hline 1 & Nov & 26.9 & 30.4 & 22.3 & 71.7 & 72.5 & 59.8 \\
2 & Dec & 25.7 & 28.2 & 24.5 & 74.3 & 77.9 & 51.7 \\
3 & Jan & 26.0 & 29.5 & 25.2 & 70.3 & 79.9 & 52.2 \\
4 & Feb & 27.1 & 29.3 & 23.8 & 65.8 & 78.6 & 50.0 \\
\hline
\end{tabular}

Table 3: Effect of rice bran supplement on the number of contaminated bags and crop period of oyster mushrooms cultivated on four substrates treatment.

\begin{tabular}{llll}
\hline Substrate & $\begin{array}{l}\text { Number of Crop } \\
\text { contami- } \\
\text { nated bags }\end{array}$ & $\begin{array}{c}\text { pe- Repli- } \\
\text { riod (days) }\end{array}$ & $\begin{array}{l}\text { cations } \\
\text { catal }\end{array}$ \\
\hline$T_{0}$ & 4 & 38 & 5 \\
$T_{1}$ & 3 & 31 & 5 \\
$T_{2}$ & 3 & 30 & 5 \\
$T_{3}$ & 1 & 42 & 5 \\
$T_{4}$ & 2 & 41 & 5 \\
\hline
\end{tabular}

in Table 2. Both temperature and relative humidity were within allowable limits for mushroom production [4].

\subsection{Mushroom Performance}

Oyster mushrooms (Pleurotus spp.) were cultivated on fermented sawdust substrate supplemented with various levels of rice bran. Of the twenty (25) bags inoculated in the experiment, only eleven successfully fruited with limited oyster mushrooms. $T_{0}, T_{1}$, and $T_{2}$, were unsuccessful in producing reasonable oyster mushrooms (pleurotus sp.) fruit bodies.

The un-supplemented sawdust $\left(T_{0}\right)$ recorded the highest number of contaminated bags (4 bags) while the sawdust substrate supplemented with $15 \%$ rice bran had the least number of contaminated bags ( 1 bag) though not much different from sawdust supplemented with $20 \%$ rice bran (2 bags). However, the number of contaminated bags increased with decrease rice bran supplementation. The result contradicts that of [11], who reported the number of contaminated bags increased with increase in rate of wheat bran supplementation up to the highest level of $20 \%$.

In this study, all the non-supplemented sawdust substrate (control) bags were heavily contaminated and this could probably be as a result of the materials broken down during substrate sterilization which encourage the growth of harmful pathogens that attacked and prevented the growth of mushroom development. Also, the high $\mathrm{pH}$ of the sawdust substrate may also have contributed to the contamination of the bags. However, [19] reported several causes of contamination of mushroom substrate and ways of avoiding potential contamination were also suggested. Similar contaminations in oyster mushroom substrates was reported in [20].
The number of days taken for colonization of fermented sawdust supplemented with rice bran ranged from 30 to 42 days. Fermented sawdust supplement with $20 \%$ rice bran were colonized within 41 days whereas sawdust supplemented with $15 \%$ rice bran took a little longer period and were colonized within 42 days after inoculation. This agreed with the findings of [17, 21, 22].

The result however, contradicts those of [23] who reported full colonization in Pleurotus ostreatus in 17-20 days on different substrates. However, result obtained in this study indicated that rice bran supplemented with fermented sawdust substrate below $15 \%$ had significant and depressing effects on total yield and biological efficiency (BE) of the oyster mushrooms.

This decrease in yield and Biological efficiency (BE) could probably be explained by the fact that below $15 \%$ rice bran mixture might have generated a lot of heat. This may have resulted in the overheating of the substrate which subsequently affected the mushroom growth negatively thereby leading to poor yield. This study was conducted during the dry season months under room temperature without adequate cooling facility in mushroom growing house.

Results of oyster mushrooms cultivation trials displayed in Table 3 below shows that crop period was long, due to climate and environmental conditions (dry season). However, this adverse environmental condition was responsible for the very low number of flushes produced.

\subsubsection{Substrate effect on crop yield}

The highest mean yield observed was that of the $T_{3} ; 24.5 \mathrm{~g}$ of fresh mushrooms. $T_{4}$ gave the second highest yield (17.2g), followed by $T_{2}(12.8 \mathrm{~g})$, $T_{1}(10.3 \mathrm{~g})$ and $T_{0}(8.6 \mathrm{~g})$.

The range of individual yields observed was quite wide with $15.9 \mathrm{~g}$. This variation is likely due to contaminants and/or climatic variations within the mushroom house. Close control of climate are major factors in ensuring high and consistent production [7], much of this control was forfeited with the choice of a low-cost, indoor growing facility. Green mold and Trichodermiaspp, was noted as the most prevalent contaminants. Statistical analysis of the yield revealed differences among substrates to be significant $(\mathrm{P}<0.05)$, the relationships among substrate treatments were observed. 
Table 4: Average Nutrient Concentration of Oyster Mushroom (Pleurotus sp.) For Four Replicated Treatment Substrates.

\begin{tabular}{lllllllllllll}
\hline \multirow{2}{*}{ Treatments } & \multicolumn{1}{c}{ MC } & VIT.A & VIT.B & VIT.C & Parameters & P & K & MG & CA & MN & CU & FC \\
\hline$T_{0}$ & 1.10 & 20 & 0.14 & 5.40 & 6.5 & 0.4 & 0.7 & 0.4 & 5.2 & 22.5 & 9.6 & 0.13 \\
$T_{1}$ & 2.44 & 114 & 0.26 & 22.30 & 1.3 & 0.6 & 0.8 & 0.5 & 4.5 & 76.4 & 6.8 & 0.37 \\
$T_{2}$ & 4.59 & 126 & 0.44 & 31.40 & 3.6 & 0.3 & 1.1 & 0.7 & 6.8 & 35.3 & 5.6 & 0.31 \\
$T_{3}$ & 3.77 & 147 & 0.48 & 25.50 & 2.1 & 0.1 & 1.4 & 0.5 & 13.6 & 7.3 & 5.7 & 0.33 \\
$T_{4}$ & 6.58 & 160 & 0.57 & 35.30 & 1.5 & 0.2 & 1.6 & 0.8 & 6.8 & 5.2 & 6.6 & 0.22 \\
\hline
\end{tabular}

NB: MC -Moisture Content N- Nitrogen P-Phosphorus K - Potassium Cu-Copper Mn-Manganese MG -Magnesium Ca-Calcium VIT.A-VitaminA VIT.B -Vitamin B VIT.C-Vitamin C FC- Fibre content

Table 5: Comparison of difference of means using LSD (Least Significant Difference) Difference of means table.

\begin{tabular}{|c|c|c|c|c|c|c|c|c|c|c|c|}
\hline \multirow{2}{*}{$\begin{array}{l}\text { Response } \\
\text { Variate }\end{array}$} & \multicolumn{5}{|c|}{ Treatment means } & \multirow{2}{*}{\multicolumn{2}{|c|}{ Difference }} & \multirow{2}{*}{$\begin{array}{l}\text { Standard } \\
\text { Errors } \\
\text { Difference } \\
\text { (SED) }\end{array}$} & \multirow{2}{*}{$\begin{array}{c}\text { Least } \\
\text { Significant } \\
\text { Differences at } \\
5 \% \text { level (LSD) }\end{array}$} & \multirow{2}{*}{$\begin{array}{l}\text { Standard } \\
\text { errors (SE) }\end{array}$} & \multirow{2}{*}{$\begin{array}{l}\text { Coefficient } \\
\text { of Variation } \\
\text { (CV) } \%\end{array}$} \\
\hline & $T_{0}$ & $T_{1} T_{2}$ & $T_{3}$ & $T_{4}$ & Rep & & & & & & \\
\hline $\mathrm{MC}$ & 1.10 & 2.44 & 4.50 & 3.70 & 6.58 & 3 & 10 & 0.719 & 1.602 & 0.881 & 24.0 \\
\hline Vit. A & 20.0 & 114 & 126 & 147 & 160 & 3 & 10 & 5.840 & 13.02 & 7.16 & 6.3 \\
\hline Vit. B & 0.14 & 0.26 & 0.44 & 0.48 & 0.57 & 3 & 10 & 0.557 & 0.1242 & 0.0683 & 18.1 \\
\hline Vit. $\mathrm{C}$ & 5.40 & 22.3 & 31.4 & 25.5 & 35.3 & 3 & 10 & 1.342 & 2.991 & 1.644 & 6.9 \\
\hline $\mathrm{N}$ & 6.50 & 1.30 & 3.60 & 2.10 & 1.50 & 3 & 10 & 0.884 & 1.970 & 1.083 & 36.1 \\
\hline $\mathrm{P}$ & 0.40 & 0.60 & 0.30 & 0.30 & 0.60 & 3 & 10 & 0.1592 & 0.3546 & 0.1949 & 44.3 \\
\hline $\mathrm{K}$ & 0.70 & 0.80 & 1.10 & 1.40 & 1.60 & 3 & 10 & 0.724 & 1.613 & 0.887 & 79.2 \\
\hline $\mathrm{Mg}$ & 0.40 & 0.50 & 0.70 & 0.50 & 0.80 & 3 & 10 & 0.1897 & 0.4228 & 0.2324 & 40.1 \\
\hline $\mathrm{Ca}$ & 5.20 & 4.50 & 6.80 & 13.6 & 6.70 & 3 & 10 & 1.107 & 2.466 & 1.356 & 18.4 \\
\hline $\mathrm{Mn}$ & 22.5 & 76.4 & 35.3 & 7.30 & 5.20 & 3 & 10 & 0.893 & 1.990 & 1.094 & 3.7 \\
\hline $\mathrm{Cu}$ & 9.60 & 6.80 & 5.60 & 5.70 & 6.60 & 3 & 10 & 1.163 & 2.591 & 1.424 & 20.8 \\
\hline $\mathrm{Fe}$ & 0.13 & 0.37 & 0.31 & 0.33 & 0.22 & 3 & 10 & 0.03084 & 0.06872 & 0.03777 & 13.8 \\
\hline
\end{tabular}

\subsubsection{Crop period}

The duration of the incubation phase, the fruiting phase, and the overall crop period (Sum of incubation and fruiting) for each substrate treatment are presented in the Table 3 above.

The average crop period for $T_{0}$ was 38 days, while that of $T_{4}$ was slightly longer at 41 days. The difference among treatments was not found to be statistically significant $(\mathrm{P}<0.50)$. With regards to substrate, $T_{2}$ exhibited the shortest crop period (30 days). While $T_{3}$ was the longest (42 days). However, differences observed were not statistically significant $(\mathrm{P}<0.50)$. Relative to findings of other studies, all four treatments supported a relatively cropping period for this particular species of pleurotus [24].

\subsubsection{Substrate effect on nutrient concentration}

The mushroom nutrient content of all the treatment substrate produce were determined.

Very little variation was found when the mineral concentrations of fruiting bodies grown on different substrates were analyzed. Of the twelve minerals analyzed, phosphorus $(\mathrm{P})$, potassium $(\mathrm{K})$ and magnesium $(\mathrm{Mg})$ did not exhibit significant differences among the fruit bodies grown on various substrates. While, Manganese (Mn) and Vitamin $\mathrm{C}$ has significant differences among all the fruit bodies grown on various substrates. Nutrient levels of pleurotus cultivated on all substrates treatment are comparable to those reported levels of oyster mushrooms grown on straw [25]. Nitro- gen levels, generally reported as protein content, are high.

\subsection{Data Analysis}

The data collected was analysed and the significance of treatment means was tested at $5 \%$ probability level using F-LSD and presented in Table 5. Among the measured parameters shown in Table 4 and Table 5, Phosphorus (P), Potassium (K) and Magnesium (Mg) none exhibited significant differences among the fruit bodies grown on various substrates. While, Manganese (Mn) and Vitamin $\mathrm{C}$ has significant differences among all the fruit bodies grown on various substrates.

\section{CONCLUSIONS AND RECOMMENDA- TIONS}

The controlled environment for oyster mushroom cultivation in rural areas of South-eastern part of Nigeria was successfully developed with locally sourced materials in this research. Findings from both temperature and humidity monitored from the mud-walled and thatched-roofed mushroom growing house after the no load test satisfied the conditions necessary for indoor fruiting site. The substrate combination $T_{3}$ gave both the highest yield and the biological efficiency, while rice bran supplement below $15 \%$ to fermented sawdust substrate may result in significantly lower mushroom yield and poor performance as observed in this study with $T_{0}, T_{1}$ and $T_{2}$ being largely unsuccessful. 
It is recommended that wider range of sawdust combination with rice brans should be studied under varying seasons and more controlled environment with enhanced design parameters. A comparative test to determine the impact of the controlled environment on overall yield is recommended.

\section{References}

[1] J. Nijjar and D. Stafford, "Undernutrition and growth in the developing world," Current Opinion in Endocrinology \& Diabetes and Obesity, vol. 26, no. 1, pp. 32-38, 2013

[2] C. Vila, M. Saracino, G. Falduto, M. Calcagno, S. Venturiello, A. Pallaro, and P. Baldi, "Protein malnutrition impairs the immune control of trichinella spiralis infection," Nutrition, vol. 60, pp. 161-169, 2019 .

[3] "Monthly report on food price trends," FAO-Global Information and Early Warning System on Food and Agriculture (GIEWS), 2018, fAO Food Price Monitoring and Analysis (FPMA) Bulletin \#1.

[4] T. Ha and C. Wang, "The effects of temperature and nutritional conditions on mycelium growth of two oyster mushrooms (pleurotus ostreatus and pleurotus cystidiosus)," Mycobiology, vol. 43, no. 1, pp. 14-23, March 2015.

[5] M. Josiane, M. Estelle, and N. Francis, "Effect of substrates on nutritional composition and functional properties of pleurotus ostreatus," Current Research in Agricultural Sciences, vol. 5, no. 1, pp. 15-22, 2018.

[6] J. Lee, Coloured Korean Mushrooms. Seoul, Korea: Academy Press, 1993.

[7] P. Stamets, Growing gourmet and Medicinal Mushrooms. Berkeley, CA: Ten Speed Press, 2000.

[8] C. Sanchez, "Cultivation of pleurotus ostreatus and other edible mushrooms," Applied Microbiology and biotechnology, vol. 85, pp. 1321-1337, 2010.

[9] S. Chang and P. Miles, Mushrooms: cultivation, Nutritional value, medicinal effect and Environmental Impact. Boca Raton: XRC Press, 2000.

[10] U. K'ues and Y. Liu, "Fruiting body production in basidiomycetes," Appl Microbiol Biotechnol, vol. 54, pp. 141152,2000

[11] P. Oei, "Manual on mushroom cultiᄀvation: Techniques, species and opportunities for commercial application in developing countries," TOOL Publications, 2003, amsterdam, The Netherlands.

[12] E. Szabová, L. Rohalová, and M. Hedvigy, "Semisolid fermentation of pleurotus ostreatus," J Microbiol Biotechnol Food Sci, vol. 2, pp. 1950-1958, 2013.

[13] L. Amrat, D. Samuel, and V. Beera, "Evaporative cooling system for storage of produce and vegetables - A review," J Microbiol Biotechnol Food Sci, vol. 50, no. 3, 2013, pMC3602570.

[14] J. Duffie and W. Beckman, Solar Engineering of Thermal Processes. New York: John Wiley and Sons, 1991.

[15] J. Bruce, "Ventilation of a model livestock building by thermal buoyancy," Trans. ASAE, vol. 25, pp. 1724$1726,1982$.

[16] Henderson and Perry, "Progress in new crops," Specialty Mushrooms, vol. 25, pp. 464-475, 1976, aSHS Press.

[17] D. Royse, T. Rhodes, S. Ohga, and J. Sanchez, "Yield, mushroom size and time to production of pleurotus cornucopiae (oyster mushroom) grown on switch grass substrate spawned and supplemented at various rates," Bio resource Technology, vol. 19, pp. 85-91, 2004, experimental Agriculture and Horticulture.

[18] N. Ngoni, "Appropriate technology cold store construction from rwanda," Chemonics International Inc., 2002.

[19] R. Kurtzman, "Pasteurization of mushroom substrate and other solids," Afr. J. Environ. Sci. Technol., vol. 4, no. 13, pp. 936-941, 2010.

[20] N. Mazumder and Y. Rathaiah, "Management of fungal and bacterial contamination in oyster mushroom spawn," Mushroom Research, vol. 10, pp. 113-115, 2001.
[21] T. Oseni, S. Dlamini, D. Earnshaw, and M. Masarirambi, "Effect of substrate pre- treatment methods on oyster mushroom (pleurotus ostreatus) production," Int. J. Agric. Biol., vol. 14, pp. 251-255, 2012.

[22] K. Khare, J. Mutuku, O. Achwania, and D. Otaye, "Production of two oyster mushrooms, pleurotus sajor-caju and p. florida on supplemented and un-supplemented substrates," Bots. J. Agric. Appl. Sci., vol. 6, pp. 4-11, 2010

[23] Z. Shah, M. Ashraf, and C. Ishtiaq, "Comparative study on cultivation and yield performance of oyster mushroom (pleurotus ostreatus) on different substrates wheat straw, leaves, saw dust," Pakistan J. Nutr., vol. 3, pp. 158-160, 2004.

[24] A. Philippoussis, G. Zervakis, and P. Diamantopouou, "Bioconversion of agricultural lignocellulosic wasters through the cultivation of edible mushrooms agrocybeaegerita, volvariella, volvacon and pleurotus spp," World. Journal of Microbiology \& Biotechnology, vol. 17, pp. 191-200, 2001.

[25] Z. Bano and S. Rajarathnam, "Pleurotus mushrooms. part ii. chemical composition, nutritional value, postharvest physiology, preservation and role as human food," CRC Critical Reviews in Food Science and $\mathrm{Nu}$ trition, vol. 27, pp. 87-102, 1988. 